\begin{tabular}{|c|c|c|}
\hline$\overline{\bar{z}}$ & $\begin{array}{c}\text { International Journal of Current Research } \\
\text { and Academic Review }\end{array}$ & 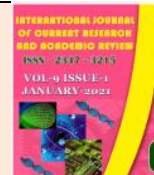 \\
\hline $\begin{array}{l}\text { EXCELLENT } \\
\text { PUBLISHERS }\end{array}$ & $\begin{array}{c}\text { ISSN: 2347-3215 (Online) Volume } 9 \text { Number } 01 \text { (January-2021) } \\
\text { Journal homepage: http://www.ijcrar.com }\end{array}$ & \\
\hline
\end{tabular}

doi: https://doi.org/10.20546/ijcrar.2021.901.010

\title{
Effect of Plant Spacing on Yield and Yield Components of Potato (Solanum tuberosum L.) Cultivars at Wolaita Sodo University, Ethiopia
}

\author{
Taye Buke*, Tsigereda Asefa and Woldemariam Woelore
}

Wolaita Sodo University

*Corresponding author

\section{Abstract}

Potato is a very important food and cash crop in Ethiopia, especially in the high and mid altitude areas. It is important to choose and adjust potato cultivars with appropriate population per unit area to get for better yield and quality. This experiment was conducted with the objective to determine appropriate plant spacing for different potato cultivar at Wolaita Sodo during belg cropping season. The experiment was arranged in a Factorial combination of three plant spacing $(60 \times 30,75$, 30 and 90x $30 \mathrm{~cm})$, and four potato cultivars (Belete, Gudene, Chala and Local) in a randomized complete block design (RCBD) with three replications. Results revealed that both the main effect of cultivars and plant spacing significantly $(P<0.05)$ affected yield and yield components of potato while their interaction is non-significant $(\mathrm{P} \geq 0.05)$ for most of the parameters considered. Days to flowering, days to maturity, plant height, leaf area index, total tuber yield (TTY), average tuber weight per plant, marketable tuber yield (MTY), unmarketable tuber numbers, dry matter content and harvest index were significantly affected by main effect of cultivar and plant spacing. Days to $50 \%$ emergency and stem number per hill were influenced only by the main effect cultivar. Whereas, marketable tuber numbers and total tuber numbers were significantly affected by the interaction effects of cultivars and plant spacing .Total tuber yield $34.40 \mathrm{t} / \mathrm{ha}$ ) and marketable tuber yield (29.31 t/ha) of cultivar Gudene were significantly higher than TTY (23.71 t/ha) and MTY (18.43 t/ha) of Local cultivars. Cultivar Gudene produced $45.08 \%, 17.96 \%$ and $6.6 \%$ more TTY over Local, Chala and Belete respectively. However, the result was statistically in par with cultivar Belete. Cultivar Gudene and Belete produced more than one fold MTY over Local cultivar. Regarding spacing, the highest total tuber and marketable tuber yield recorded from $60 \mathrm{~cm}$ inter row spacing and the lowest from $90 \mathrm{~cm}$ and $75 \mathrm{~cm}$ inter row spacing resulted intermediate yield. Therefore, from this study, it can be concluded Gudane and Belete cultivars at a plant spacing of $60 \times 30 \mathrm{~cm}$ and $75 \times 30 \mathrm{~cm}$ resulted in highest marketable tuber yield could be recommended to potato growers in the study.
\end{abstract}

\section{Introduction}

Potato (Solanum tuberosum L.) is originated in the highlands of the Andes in South America (Asfaw, 2016) and was brought to Europe in the 16th century. It is a crop of major economic importance worldwide and is one of the tuber crops important for human diet in terms of energy and protein sources .The relatively high carbohydrate and low fat content of potato makes it an excellent energy source for human consumption (Abay Ayalew and Tesfaye Dejene, 2011). In the world today, millions of people particularly, in the developing 
countries depend on potato production for subsistence (FAO, 2008). As a result, potato is considered as staple food crop in some countries and as vegetable in others (Zamil et al., 2010).

Ethiopia is endowed with suitable climatic and edaphic conditions for potato production. About $70 \%$ of the available agricultural land is located at an altitude of 1800-2500 meters above sea level and receives an annual rainfall of more than $600 \mathrm{~mm}$, which is suitable for potato production (Gebremedhin et al., 2008) .Besides; potato is also suited to smallholder farmers in developing countries for the labor requirement. Its shorter growing period makes it possible for smallholder farmers to use this crop in a system where more than one crop is possible on the same land per season.

In Ethiopia, among root and tuber crops potato ranks first in volume produced and consumed followed by cassava, sweet potato and yam (CSA, 2016). It is grown by 1,571,806 farmers, cultivating 74, 935 hectares per season with an annual production of 0.86 million tons (CSA, 2017). Four major potato growing areas (central, eastern, north-western, and southern) Ethiopia comprises approximately $83 \%$ of the potato producing farmers (Hirpa et al., 2010). It is cultivated by about 21, 3, 23, and $36 \%$ of potato producing farmers in central, eastern, north-western, and southern part of the country, respectively with an average yield range from8-10, 1113, 14.3-20.3, and 14.1-20.4 $\mathrm{t} \mathrm{ha}^{-1}$ in the same order (CSA, 2017). Despite high potential production environments and marked growth, the national average potato yield in Ethiopia is $13.9 \mathrm{t} \mathrm{ha}^{-1}$ (CSA, 2018), which is lower than the experimental yields of over $38 \mathrm{t}$ ha- 1 . Many factors influence potato yield and quality such as cultivars, plant population, soil type, weather conditions, water management, fertilization, seed piece size, pests and diseases (Khalafalla, 2001).

In Ethiopia, lack of appropriate agronomic techniques is known to be one of the major contributing factors to the existing low tuber yield per unit area despite the existence of highly suitable edaphically and climatic condition for potato productivity (FAOSTAT, 2008). Emerging research outcomes from various parts of Ethiopia demonstrated that plant density per a unit area is important factor that affects the tuber yield and yield components of potato (Bussan et al., 2007; Arega et al., 2018). Plant density in potato affects some of important plant traits such as total yield, the quantity of marketable tuber numbers, unmarketable tuber numbers and quality of the produced potato (Marguerite et al., 2006; Kinde. and Asfaw. 2016), seed cost, plant development, yield and the quality of the crop (Bussan et al., 2007). Variation in the population causes changes in the light intensities, humidity and temperature within canopies. Too close spacing interferes with normal plants development and increases competition for moisture, mineral nutrients, and light and hinder harvest operations (Ratta et al., 1991) resulting in yield reduction and is also similar to decreasing the concentration of growth factors (Norman, 1992). Whereas, too wide spacing may result in excessive vegetative growth of plant and abundant weed population due to more feeding space available.

Under the aforementioned situations the optimization of plant density is one of the most important subjects of potato production management, because it affect seed cost, plant development, yield and quality of the crop (Bussan et al., 2007). According to Alemayehu et al., (2015), most of the varieties released in Ethiopia were planted at the spacing of $75 \mathrm{~cm}$ between rows and $30 \mathrm{~cm}$ between plants while CASCAPE project demonstration recommended inter row spacing of $60 \mathrm{~cm}$ and intra row spacing of $30 \mathrm{~cm}$ for optimum ware potato production (Asresie et al., 2015). On the other hand, farmers in Ethiopia are using different spacing below or above the national recommendation many factors including lack of site specific recommended inter and intra row spacing (Arega et al., 2018). Gebru et al., (2017) also reported that farmers at Wolaita areas have using low seeding rate $(1.5 \mathrm{t} / \mathrm{ha})$ than the recommended amount of seeding rate ( $2 \mathrm{t} / \mathrm{ha}$ ) due to inaccessibility of improved seed tubers. Therefore, most of smallholder's farmers in Wolaita area use Local cultivars in lower seeding rate than the national recommendation.

However, the choice of plant spacing is not related to the level of production alone, but also to the choice of potato cultivar to be grown. Improved potato varieties together with improved management is proved to give three to four fold yield advantage as compared to Local varieties with traditional production management practices (Mahmood 2005). Even though, in Ethiopia different research centers and universities have released several high yielding potato varieties, most of smallholder farmers at Wolaita areas have cultivating Local cultivars with higher plant density per unit area. The possibility of securing high yields depends much upon a proper consideration of optimum number of plants per unit area and the pattern in which the given quantity of seed or plant population is arranged in the field (Endale and Gebremedhin, 2001). Thus, it is important to choose and 
adjust cultivar with appropriate plant population per unit area, for a better yield, more marketable tuber size, good quality seed tuber and appropriate agronomic practices. Therefore, site specific research to study and recommend optimum plant spacing for different potato cultivars is required to increase production and productivity.

Thus this research was initiated to achieve the following objective

To assess the effect of cultivar and plant spacing on tuber yield and yield component of potato at Wolaita Sodo

To recommend appropriate cultivar and plant spacing for potato growers in the study area

\section{Literature review}

\section{Botanical description of potato}

Potato (Solanum tuberosum L.) is a root vegetable, belongs to the family Solanaceae or the Nightshades and a family of about 90 genera and 2800 species. In many contexts, the word potato refers to the edible starchy tuber portion of the plant, but it can also refer to the plant itself. It is an annual plant that produces edible underground mature tubers that are used as vegetable (Struik and Wiersema, 2001). It belongs to the genus Solanum, which presents species with different ploidy levels, varying from diploid $(2 n=24)$ to hexaploid $(6 n=$ 72). Rosa et al., (2010) noted that Solanum tuberosum L., which is tetraploid $(4 n=48)$, is the most commonly cultivated species.

Potato is cross-pollinated mostly by insects including bumblebees which carry pollen from other potato plants, but a substantial amount of self-fertilization occurs as well. Potato varieties can be propagated vegetatively by planting tubers, pieces of tubers cut to include at least one or two eyes and "true seeds" or botanical seeds. Its tuber is an enlarged portion of an underground steam or stolon.

Potato has a relatively shallow, fibrous root system with the majority of the roots are concentrated in the top soil surface at about $0.3 \mathrm{~m}$. The root system develops rapidly during early growth and achieves maximum development by mid-season. Thereafter, root length, density and root mass decrease as the plant matures. The flowers produced in clusters or cymes are yellow, white, red, blue, pink or purple with yellow stamens, but are rarely produced under conditions in which day lengths are short and temperatures are high. In general, the tubers of varieties with white flowers have white skins, while those varieties with colored flowers tend to have pinkish skins (Winch, 2006). The fruits are globular berries and contain poisonous alkaloids (Solanine).

The stem is angular, branched and bears compound, alternate leaves up to $30 \mathrm{~cm}$ long. Its compound leaves manufacture starch that is transferred to the ends of its underground stems (or stolons). The stems thicken to form a few or as many as 20 tubers close to the soil surface. The number of tubers that actually reach maturity depends on available moisture and soil nutrients. Tubers may vary in shape and size, and normally weigh up to $300 \mathrm{~g}$ each. At the end of the growing season, the plant's leaves and stems die down to the soil level and its new tubers detach from their stolons. The tubers then serve as a nutrient store that allows the plant to survive the cold and later regrow and reproduce. Each tuber has from two to as many as 10 buds (or "eyes"), arranged in a spiral pattern around its surface. Eyes concentrated near the stolon or basal end. Eye number and distribution are characteristic of the cultivar. The buds generate shoots that grow into new plants when conditions are again favorable.

\section{Importance of potato}

Potato is one of the most important food crops in the world after rice and wheat (Vleeshouwers et al., 2011). Currently, potato is produced in more than 100 countries and consumed by over a billion people worldwide. Potato is called the hunger breaker crop as it has a short crop cycle ( $<120$ days) compared to cereal crops like maize. It is regarded as a high-potential food security crop because the crop produces large quantities of dietary energy ( 30 to $35 \mathrm{t} / \mathrm{ha}$ starch based produce in 3 to 4 months) and has relatively stable yields under conditions in which other crops may fall (Gebremedhin et al., 2008; FAO, 2010).

It represents an important component of human diet, because tubers are able to supply several nutrients, such as essential amino acids, vitamins (as vitamin C) and minerals (Melito et al., 2017). Potatoes are approximately $80 \%$ water and $20 \%$ solids, although this can vary by several percentage points depending on the cultivar. Of the 20 grams of solids in a 100 gram tuber, about 18 grams are carbohydrate and 2 grams protein. It should become one of the main nutritional components, since it is a rich source of energy and valuable food. Experts of the Food and Agriculture Organization of the 
United Nations called people's attention to nutritional and wholesome properties of potato, for its proteins are very valuable and one middle-sized potato covers half the daily requirement for vitamin $\mathrm{C}$ and one-fifth of the requirement for potassium (Ceglarek and Zarzecka, 2003).

Potato has a very high satiety index compared to foods with an equivalent carbohydrate content and this represents a very positive aspect of potato nutrition. According to FAO report, potato is a staple food for more than 600 million people who live in sub-Saharan Africa. The crop particularly has potential for fertile and waste land where other crops could not survive, to help overcome food shortage (Gebremedhin et al., 2013).

The high nutrient content, ability to adapt to marginal environments, relatively ease of cultivation, and low cost and high productivity are attributes that make potatoes one of the principal and most important sources of food and income for underprivileged citizens of developing countries around the world.

Potato is primarily grown for its starchy tuberous root; its flour can be produced for soup, biscuits, bread, and chips. The leaves used as animal feed in the developing countries. In Ethiopia, potato production could fill the gap in food supply during the hungry months of July to August before the grain crops are being harvested.

\section{Climatic requirements}

Knowing about climatic requirements of potato and its physiological responses to the environment is extremely important to help growers produce high yields with good tuber quality under site-specific conditions.

The potato is essentially a "cool weather crop", with temperature being the main limiting factor. In tropical areas, potato should be grown where the climate is tempered by altitude $(1500-4200$ masl) or at lower altitudes provided that the crop is grown during the cool season. The ideal condition for tuberization is a night temperature of around $16^{\circ} \mathrm{C}$, while tuber growth is sharply inhibited in temperatures below $10^{\circ} \mathrm{C}$ and above $30^{\circ} \mathrm{C}$, while optimum yields are obtained where mean daily temperatures are in the 18 to $20^{\circ} \mathrm{C}$ range. The growth rate decreases with increasing temperature above $21^{\circ} \mathrm{C}$ and finally stops at $30^{\circ} \mathrm{C}$.
The potato can be grown almost on any type of soil, except saline and alkaline soils. Naturally loose soils, which offer the least resistance to enlargement of the tubers, are preferred, and loamy and sandy loam soils that are rich in organic matter, with good drainage and aeration, are the most suitable. Soil with a $\mathrm{pH}$ range of 5.2-6.4 is considered ideal. Planting on poorly drained soils usually results in a poor plant stand due to seed piece decay and poor-quality potatoes at harvest. Potatoes are less susceptible to scab when soil $\mathrm{pH}$ is between 5.0 and 6.5. If $\mathrm{pH}$ is too low, apply dolomitic limestone. Better tuber yields have been obtained from potatoes grown at soil reaction ranging from $\mathrm{pH} 5.0$ to 7.0 (AGRISNET, 2010).

The root system of the potato plant is not extensive and ample soil water is necessary whether from rain or supplemental irrigation. Good water penetration and aeration are musts for proper growth and tuber formation. Excessive tillage and land preparation cause compaction and should be avoided. To be effective, the soil should be plowed below any compacted layer within the normal root zone, and then disk harrowed before planting. Spike-tooth harrowing to break up clods and level the soil may be needed just prior to planting.

\section{Effect of plant spacing on growth of potato}

Potato is heavy nutrient feeder crop and the nutrients have an important role in improvement of productivity and quality of vegetable crops. Plant spacing is an important factor determining potato yield and component. The growth rate of a potato crop depends on well supplied with water and nutrients and free from pests and diseases are about proportional to its light absorption (Van Delden, 2001).

Plant growth analysis is usually based on total land, plant parts dry matter, size and numbers of different parts per plant or per sample and number of shoots per unit ground area. From these values growth characteristics (various indexes, ratios and coefficients) are calculated. These growth characteristics allow describing the growth of the plant or plant organ and the relationship between the assimilatory apparatus and dry matter production (Sands et al., 1983).

More space meant that plants were able to exploit the available nutrients in the soil and the photosynthetic active radiation for growth than plants at close spacing. In other words, the growth rate was increased. Van der Zaag et al., (1990) studied the response to plant 
population under two different sites; one temperate and the other tropical. At the temperate site, closer spacing increased plant height. At the tropical site, closer spacing decreased plant height when canopy cover did not reach $100 \%$.

\section{Effect of plant spacing and density on yield of potato}

Plant density is the number of plants per unit area and is inversely related to the distance between plants within a row. Altering plant density and row spacing changes the radiative transport within the canopy. In crop production, canopy development is very important to optimize light interception, photosynthesis and dry matter accumulation to harvestable parts. So crop canopy can be managed by alternating row spacing and plant population; as the plant density increases, yield per unit area also increases on onion crop (Silvertooth, 2001).

Average tuber weight and tuber number are reported to be an important components determining tuber yield (Elfinesh, 2008). Geremew et al., (2010) explained that spacing has effect on different cultivar as their toot and leaf growth habits. The optimum use of spacing or plant density has dual advantage. It avoids strong competition between plants for growth factors such as water, nutrient and light. In addition optimum plant population enables efficient use of available crop land without wastage.

Bussan et al., (2007) found that optimizing plant density was one of the most important practices in potato production management, as it affects seed cost, plant development, yield and the quality of the crop. According to Georgakis et al., (1997) report when increasing plant density, the tuber yield was also increased. Plant density strongly affected yield, both by number and by weight, and more tubers and yield per square meter were expected in higher plant densities (Karafyllidis et al., 1997). According to Alvin et al.(2007) report with increasing plant density, yield of potato increased. On the other hand, increase in plant density, probably is the reason of the lack of nutrient elements for each plant or production of more tubers per unit area and reduction of their mean size. Increase in plant density decreases mean tuber size probably because of plant nutrient elements reduction, increase in interspecies competition and large number of tubers produced by high numbers of stems (Khajehpour, 2006).

Mauromicale et al., (2003) concluded that when reducing plant population the yield was increased. Work by Güllüoglu and Arioglu (2009) revealed that major yield components; mean tuber weight and tuber yield per plant, significantly decreased as planting distance got closer due to increasing inter-plant competition. Increase in plant density enhances the marketable yield than the total yield. Khalafalla (2001) attributed this to increased number of tuber per unit area, more tubers per plant required. In a study by Masarirambi et al., (2012), yield was not affected by population density although they did not examine the tuber size distribution which would have shown an increase in smaller tubers with increased plant population. The high number of tubers at high densities may be accounted for by the fact that at low density plantings, fewer sinks are produced per unit area and increase as the planting density increased. This is in contrast with Masarirambi et al., (2012); Güllüoglu and Arioglu (2009) who explained that the availability of space had an effect on number of tubers formed, that the greater the space, the higher the number of tubers was formed.

\section{Response of potato cultivars to plant spacing}

Potato cultivar variation in yield can be analyzed in terms of differences in cumulative light absorption. Van Delden (2001) determined that total biomass production and accumulation of potato cultivars are dependent on the absorbed photosynthetically active radiation (PAR), which is directly proportional to the plant canopy cover. Leaf radiation absorption is governed by the rate of leaf appearance, leaf expansion, leaf size, geometry and directions

Potato cultivars do differ in the production of leaves at low temperatures in such a way that horizontal leaves intercept lighter than erect leaves at low 1AI, and most cultivars differ considerably in this character. According to Damavandi and Asle- Gorgani (2005) report the number of stems plant-1 at maturity, stem and leaf dry weight at maturity, and tuber dry weight compared to shoot dry weight were significant due to cultivar and density. A significant difference has among cultivar in plant height, number of branches, leaf area, tuber number and tuber weight (Alsharari et al., 2007). Abong et al., (2010) reported that specific gravity, dry matter content differed significantly among the different potato cultivar. Potato crop growth and tuber yields have been linked to the duration of the growth cycle, which depends on climate, cultivar, and crop management (Kooman et al., 1996a, 1996b). Saluzzo et al., (1999) also reported that variety with higher average tuber weight in addition to its late maturity might also be more efficient in dry matter partitioning to tubers than variety with lower average tuber weight 


\section{Materials and Methods}

\section{Description of the study area}

The field experiment was carried out during belg season from February to May in 2019 at Wolaita Sodo University (WSU) research and practical farm, Southern Ethiopia. Geographically, WSU is located in $06^{\circ} 50^{\prime} 00^{\prime}$ ' $\mathrm{N}$ latitude and $37^{\circ} 45^{\prime} 07^{\prime}$ ' $\mathrm{E}$ longitude range at an altitude of 1882 meters above sea level. The annual average rainfall of the area was $1212 \mathrm{~mm}$ and characterized by having a bi-modal rainfall pattern that forms two cropping seasons' viz. belg (February-May) and meher (June-September). The average minimum and maximum air temperatures of the area are $13.5^{\circ} \mathrm{C}$ and $23^{\circ} \mathrm{C}$, respectively. The soil type of the study area is characterized by Nitisol with slightly acidic $(\mathrm{pH} 5.9)$ with low content of organic carbon (OC) $(0.17 \%)$, total nitrogen $(0.01)$ and available $\mathrm{P}(5.4 \mathrm{mg} / \mathrm{kg})$. It also has sandy textural class (Ermias and Fanuel, 2020).

\section{Experimental materials}

The potato cultivars used in this study included two selections (improved varieties) 'Belete', 'Gudene' and 'Chala' and one 'Local'. Seed tuber was one year old having at least five active buds and well prepared for seed purpose. Potato seed tuber used in the experiment which was collected from Holata agricultural research center and from Delbowogene kebele.

\section{Treatments and experimental design}

Three levels of inter row spacing $(60 \mathrm{x} 30 \mathrm{~cm}, 75 \times 30 \mathrm{~cm}$, and90x $30 \mathrm{~cm}$ ), by $30 \mathrm{~cm}$ of intra-row spacing, and four potato cultivars (Belete, Gudene, Chala and Local)was arranged in $3 \times 4$ factorial arrangement in Randomized Complete Block Design (RCBD) replicated three replications. Each experimental unit had $3.6 \mathrm{~m}$ length and $2.7 \mathrm{~m}$ width with a total net area of $9.72 \mathrm{~m}^{2}$.Each experimental unit length was divided into four, five and six rows at $90 \mathrm{~cm}, 75 \mathrm{~cm}$ and $60 \mathrm{~cm}$ intervals, respectively. $0.75 \mathrm{~m}$ between plots and $1 \mathrm{mbetween}$ block was left for foot path.

\section{Experimental procedures and agronomic practices}

The experimental land was well prepared using tractor and manually. Each row was opened at $20 \mathrm{~cm}$ depth (i.e. average plough layer) and seeds were planted. All treatments were fertilized with recommended rate of 236 $\mathrm{kg} \mathrm{NPS} \mathrm{ha}{ }^{-1}, 194 \mathrm{~kg}$ urea ha ${ }^{-1}$. The entire rate of NPS and the half rate of the urea fertilizer were applied at the time of planting, while the remaining half of the urea was applied at flowering stage. Cultural practices such as cultivation, ridging and weeds were carried out as per the research recommendation required for potato production.

\section{Data collection and measurements}

\section{Phenology and growth related traits}

Date of emergence: refers to the days of $50 \%$ of the plants per plot were emerged.

Days to 50\% flowering: the number of days from planting to $50 \%$ flowering were recorded when $50 \%$ of the plants produce flowers in each plot.

Days to maturity: the number of days from planting to maturity were recorded when $90 \%$ of the plants in each plot become ready for harvest as indicated by the senescence of the haulms.

Number of stems/hill: the average number of five randomly selected plants main stem were counted and recorded from each plot.

Plant height (cm): the average of five randomly selected plants height from base of the stem to shoot apex were measured and recorded at flowering stage.

Leaf area index (LAI): was recorded from five randomly selected plants in each plot and from each plot, the areas of three sample leaves taken from upper, middle and lower portions of the plant were measured using a meter from each plant. Leaf area calculated as W $\mathrm{x} \mathrm{L} \mathrm{x} \mathrm{0.674.} \mathrm{Where} 0.674$ is the correction factor (Djilani and Senoussi, 2013). Leaf area index was calculated by dividing total leaf area to the respective land area occupied by the plants.

\section{Tuber yield, yield components and quality}

Total tuber yield (t/ha): the total tuber yield were recorded by adding up the weights of marketable and unmarketable tubers and converted to total yield per hectare.

Average tuber yield g/plant: Mean weight of marketable and unmarketable tubers produced from middle row was recorded after harvest and expressed in gram using a sensitive balance. 
Marketable yield ( $t / h a)$ : average of randomly selected five plants of tubers greater than or equal to $20 \mathrm{~g}$ in weight and healthy were weighed in $\mathrm{kg} / \mathrm{plot}$ and converted into $\mathrm{t} / \mathrm{ha}$.

Non-marketable tubers(t/ha): average of randomly selected five plants of tubers which are less than $20 \mathrm{~g}$, rotten and greened was measured and recorded at harvest time.

Total tuber number $\mathbf{h a}^{-1}$ : the total tuber number (marketable and non-marketable) of harvested tubers were counted per plot and converted to total tuber number per hectare recorded.

Average tuber number per plant: It was measured marketable and unmarketable after harvest and expressed as number of tubers per plant.

Number of marketable tubers $\mathbf{h a}^{-1}$ : randomly selected five plant tubers per plot which are tuber size greater than $20 \mathrm{~g}$ was measured and counted and converted in to hectare at the harvesting stage.

Number of unmarketable tubers $\mathrm{ha}^{-1}$ : randomly selected five plant tubers per plot which are under-sized tubers $(<20 \mathrm{~g})$ as well as diseased, cracked and rotten were measured and counted at harvest time converted into $\mathrm{t} / \mathrm{ha}$.

Dry matter (\%): five fresh tubers randomly selected in each plot and weighed. Tubers were sliced and dried in an oven at $70^{\circ} \mathrm{C}$ until constant weight. Dry weight was recorded and dry matter percent was calculated according to as:

\section{Dry weight X 100}

Dry matter\% =

Fresh weight

Harvest index (HI): was determined as the ratio of dry weight of the tubers to the dry weight of the total plant biomass measured from five randomly taken plants at harvest, and this can be use as a measure of reproductive efficiency.

\section{Data analysis}

Data on different parameters were subjected to Analysis of Variance (ANOVA)using SAS Computer software version 9.0 (SAS Institute Inc., 2008). When ANOVA showed significant differences for the measured traits, mean separation was carried out using Least Significant difference(LSD) test at 5\% level of significance.

\section{Results and Discussions}

\section{Days to 50\% emergency}

Day to $50 \%$ emergency of potato plant was shown significant $(\mathrm{P}<0.05)$ difference among the cultivars but not for inter row spacing and its interaction (Table 3 and appendix 1).Cultivar Local had significantly longer days to $50 \%$ emergency (16.6 days) while cultivar Chala had took shorter days to $50 \%$ emergency (13.82). Variation in emergency may be governed by genetic factors though it is influenced by the locations where the varieties are grown and agronomic management such as nutrient supply. Different cultivars had different capacity to store food and to provide an optimal supply of carbohydrate for the emerging seedling of embryo. The result is in agreement with the findings of Abubaker et al., (2011) who reported that the genetic variation could be attributed to the emergency difference among varieties.

\section{Days to flowering}

The result indicates that cultivars and plant spacing showed highly significant $(\mathrm{P}<0.01)$ differences on mean number of days to flowering (Appendix1). However, the interaction effect of spacing and cultivar did not showed significant effect on days to flowering (Table 2).

Local cultivar had taken longest days to flowering (55.26 days) with statistical parity with Gudane and followed by Gudene and Belete (54.96 and52.74) respectively and while Chala cultivar had took shortest days to flowering (49.37 days).However, Local and Gudene cultivar are statistically similar. This might be due to the difference in environmental adaptability among varieties and the indicators of the traits that mostly controlled by genetic factors. The result supported by Arega et al., (2007)who reported that there were considerable differences between varieties in respect to days to $50 \%$ flowering this is due to that days to flowering is highly dependent on gene factors and governed by many environmental factors mainly temperature and light. On the other hand wider plant spacing $(90 \times 30 \mathrm{~cm})$ resulted in longer days to flowering (54.39 days) while closer plant spacing (60 $\mathrm{x} 30 \mathrm{~cm}$ ) took the shortest (52.18) days to flowering. This is probably due to tuber planted a wider space got sufficient light and nutrient that hinder the transition of vegetative stage to the reproductive stage than those planted in a closer spacing. Plants in a closer spacing may compete for the available light and nutrients this might be lead them to transacted rapidly to reproductive stage than plants that does not compute for light and 
nutrients. This result in-agrees with (Sadik et al., 2018; El-Naim, 2003) who reported that closer spacing could reduce vegetative growth and enhances flower formation on potato crop days to $50 \%$ flowering.

\section{Days to maturity}

The main effects of cultivar and inter row spacing showed highly significant $(\mathrm{P}<0.01)$ effect on days to maturity of potato while its interaction was not significant. (Table 2 and appendix 1).

The longest days to maturity (96.22 days) was recorded from Belete while the shortest days to maturity ( 86.22 days) was recorded from Chala. This might be due to the fact that maturity period is dependent on the cultivar and climatic conditions. This is in agreement with the report of Musa et al., (2007) who noted that the maturity is a varietal characteristic which of course can be influenced by planting date, climatic condition and adopted cultivation practices.

On the other hand, the earliest days (88.58) to maturity was recorded at closer spacing $(60 \times 30 \mathrm{~cm})$ whereas prolonged days (93.42) to maturity were recorded from wider spacing $(90 \mathrm{~cm} \times 30 \mathrm{~cm})$. Increasing plant spacing delayed the time required to reach maturity. Rapid maturity in response to closer planting space is indicator of competition for growth factors while at wider spacing the competition is less which favor growth and extend days to maturity. The current finding is in agreement with Mengistu and Yamoah(2010) and Birhanu et al.(2016) who reported that increasing plant density had shortened days to maturity. Similarly Harnet (2011) reported that wider plant spacing not only delayed maturity but also caused total yield reduction in broad area of land.

\section{Stem number}

The results of the present study showed that main effect of cultivar had showed highly significant $(\mathrm{P}<0.01)$ difference on stem number of potato whereas plant spacing and its interaction was not showed significant difference(Table3, andappendex1).

Stems density is one of the most important yield components in potato. Cultivar Belete recorded highest stem number (6.4) and lowest stem number (4.72) was recorded from Local cultivar. Cultivar Belete resulted in $35.60 \%$ and52.38\% more stems per plants compared with Chala and Local cultivars respectively. Although cultivar Belete indicated $7.6 \%$ more stems numbers over cultivar Gudene, it does not statistically different. This difference could be due to the inherent variations in the number of buds per tuber of cultivar Belete. The potato crop is usually propagated by using underground storage organs known as tubers. Potato tubers show a wide range of variation and possess a variable number of growing points (buds) arranged in groups (eyes) over their surface. This buds arranged in groups are responsible for emerging sprouts and stem numbers per plant. Different scholars reported that the stem number is the reflection of different factors, such as storage condition (Islam, 2006), physiological age of the seed of the variety and tuber size. The number of stems per plant had direct relation with the number of sprouts per tuber not on the treatment applied (Abebe et al., 2010) and the sprouts are the function of number of eyes on tubers. The result is in agreement with (Frezgi, 2007; Harnet, 2011,) who reported that the number of stems per hill was not influenced by plant density rather it is influenced by cultivar.

\section{Plant height}

Analysis of variance showed plant height was significantly $(\mathrm{P}<0.05)$ affected by the main effects cultivar and spacing (Appendix1). But its interaction not significantly affected the plant height.(Table4).

Significantly $(\mathrm{P}<0.05)$ the heights plant height had recorded from Belete $(84.1 \mathrm{~cm})$ and Gudane $(83.93 \mathrm{~cm})$ with statistical parity while the lowest plant height was recorded from Local cultivar $(63.88 \mathrm{~cm})$.As researcher observed on field as well as from the recorded data cultivar Belete and Gudene has higher and nearly similar performance on stem numbers and leaf area index (LAI) compared to another cultivars. This higher numbers of stem numbers with higher leaf numbers, LAI and overall higher canopy that favors a higher photosynthetic rate will have a higher growth rate and plant height. Therefore, the increment of plant height might be due to the ample food provided and/or due to varietal differences that could be associated with their canopy structure or other growth habit like inter node length, a parameter that was not measure in this study. These results agree with the finding of Bekele (2018) were revealed that variation among plant height was observed for varieties.

At wider planting space the longest plant height was measured and at narrower planting spacing shortest plant height was recorded. Plant height was decreased as plant 
density increase. This decreasing in plant height with increased plant density is consistent with the results of Zamil et al., (2010) who reported that the wider spacing enhances growth and height of the plant. Frezgi (2007) also noted that increasing plant spacing resulted in significant increase in pant height. The result was also agreed with the finding of Kantona et al., (2003) on onion and Wolde Mariam (2009) on ginger. This is could be due to that plants at wider spacing practiced less competition for growth resources such as water, light and nutrients and grow more vegetatively whereas, plants that exhibit intense competition decreased in height.

\section{Leaf area index}

Leaf area index (LAI) was highly $(\mathrm{P}<0.01)$ influenced both by the main effect of cultivar and plant spacing. But the interaction effect did not show the significant difference (Table4 and Appendix1).

Cultivar Gudene had the highest leaf area index, followed by cultivar Belete but statistical not different. Local cultivar had significantly lower leaf area index than other cultivar. Leaf area index indicates the level of photosynthesis and accumulation of starch for partitioning to tuber at the end of the growing season. leaf area index can vary widely according to growing conditions and variety which is in agreement with the report of Allen et al., (1992) .The rate of gross photosynthesis is almost proportional to LAI (Vreugdenhil, 2007).

The highest (3.43) leaf area index was recorded at the spacing of $60 \times 30 \mathrm{~cm}$ and the lowest at the spacing of $90 \mathrm{x} 30 \mathrm{~cm}$. Within plant spacing $60 \mathrm{~cm}$ and $75 \mathrm{~cm}$ leaf area index was not showed significance difference. Significant increases in LAI with the decreasing plant spacing from 90 to $60 \mathrm{~cm}$.

It probably could be attributed to the increase in leaf area coverage of the soil surface until sufficient light became trapped for optimally enhanced productions of photo assimilate. High LAI usually indicate that the crop can intercept more solar radiation for photosynthetic activity.

Corroborating the results of this study, Ronald (2005) who revealed that the highest density increased leaf area index, possibly indicating potential partitioning of assimilates for vegetative growth. According to Ravichandran and Singh (2003), LAI in potato increased with decreasing plant spacing.

\section{Total tuber yield (t/ha)}

Cultivar and plant spacing revealed significant $(\mathrm{P}<0.05)$ difference on total tuber yield (Table 5 and Appendix 2). However, its interaction did not significantly influence total tuber yield. Higher total tuber yield per hectare (34.40) was scored cultivar Gudene and lower total tuber (23.71) per hectare scored from Local cultivar. Cultivar Gudene was showed $45.08 \%, 17.96 \%$ and $6.63 \%$ total tuber yield increments over Local, Chala and Belete respectively. However, total tuber yield per hectare recorded from cultivar Gudene was not statistically different from total tuber yield recorded from cultivar belete.

The result regarding planting space showed that decreasing planting spacing increases total tuber yield of potato. Significantly higher $\left(32.02 \mathrm{t} \mathrm{ha}^{-1}\right)$ total tuber yield scored from closer inter row spacing $(60 \mathrm{~cm})$, intermediate inter row spacing $(75 \mathrm{~cm})$ showed fairly high yield to narrower inter row spacing while the wider inter row spacing $(90 \mathrm{~cm})$ reveled the lower $\left(27.57 \mathrm{t} \mathrm{ha}^{-1}\right)$ total tuber yield. The possible reason might be due to efficient utilization of nutrients applied, earlier in season ground coverage might be hurt weed growth and reduced its competition for nutrients and other growth factor, could be enhanced the light interception that used in assimilation, fewer lateral branches are being formed and tuber formation starts earlier. In other words, narrowing inter row space increase plant population that could be increasing total tuber yield per unit area of land. This is may be attributed with enhanced leaf area index and trapping of optimal radiation for production of photo assimilate. This result in consistence with Rajasekaran et al.(2006); Silva et al., (2008); Harnet (2011); Zebenay (2015) who reported plant density strongly affected yield, both by number and by weight, and more tubers numbers and yield per square meter were expected in higher plant densities.

\section{Tuber yield per plant}

The main effect of cultivar and plant spacing showed highly significant $(\mathrm{P}<0.01)$ differences on average tuber weight per plant (Table 5). However, the interaction effect of cultivar and spacing were statistically nonsignificant (Appendix 2).

The maximum yield per plant i.e. $764.64 \mathrm{~g}$ and $718.49 \mathrm{~g}$ for the Gudene and Belete respectively was recorded. The lowest yield (528.36) per plant was obtained from the cultivar Local. The variation may be associated to 
that cultivar with long growth period have more leisure to complete tuber initialization and storage of photosynthetically matter in the tubers and also may be due to the cultivar have inherent genetic variation on tuber bulking among potato varieties. This result is also agrees with the work of Levy (2007) who suggested that the duration and rate of tuber bulking vary among varieties and depend on environmental conditions. Tuber size is affected by the length of growth period of potato time of tuber initiation (Ankumah et al., 2003).

The potato cultivars also produced significantly different on average tuber weight per plant. The highest tuber weight $744.35 \mathrm{~g}$ recorded from spacing of $90 \mathrm{x} 30 \mathrm{~cm}$ followed by $673 \mathrm{~g}$ from the spacing of $75 \times 30 \mathrm{~cm}$ whereas a closer spacing of $60 \mathrm{x} 30 \mathrm{~cm}$ gave the lowest $(576.32 \mathrm{~g})$ average tuber yield per plant. This could be attributed to the fact that plots at higher plant densities were at intense competition among plant spacing for growth resources as a result it gave less yield per plant as compared to plots with less plant densities, where resources were not limited to support better growth and partitioning of assimilates. And also at wider spacing better plant exposure for high radiation interception that increased the photosynthetic efficiency of the plant and finally increase the average tuber weight. This result is similar with those of Sultana and Siddique (1991) who stated the yield of tubers per hill increased significantly with increase in plant spacing but the yield of tuber per hectare did not follow the same trend.

\section{Marketable tuber yield (t/ha)}

The main effect of cultivar and plant spacing have significant $(\mathrm{P}<0.05)$ effect on mean marketable yield of potato (Appendix 2); and the interaction effect of cultivars with spacing did not showed significant effect on this parameter (Table 5). Gudene and Belete cultivar had showed highest $29.31 \mathrm{t} \mathrm{ha}^{-1}$ and $27.94 \mathrm{t} \mathrm{ha}^{-1}$, respectively; marketable tuber yield compared with other treatments whereas, the Local cultivar showed the lowest $\left(18.43 \mathrm{t} \mathrm{ha}^{-1}\right)$ marketable tuber yield. Both Gudene and Belete resulted one fold more marketable tuber yield over Local cultivar. These differences could have been attributed to the difference in the genetic makeup of the varieties.

Marketable tuber yield decreased with increasing in plant spacing. For instance, at closer spacing $60 \times 30 \mathrm{~cm}$ the mean marketable tuber yield was highest $\left(26.59 \mathrm{t} \mathrm{ha}^{-1}\right)$. Conversely, the lowest yield of marketable tuber (22.97 t $\mathrm{ha}^{-1}$ ) was recorded from wider planting spacing (90 X
$30 \mathrm{~cm}$ ). Increasing inter row spacing from 60 to $75 \mathrm{~cm}$ decreased mean marketable tuber yield per hectare by $6.25 \%$, and similarly, increasing inter row spacing from 75 to $90 \mathrm{~cm}$ deceased the mean tuber yield per hectare by 8.9\%. The possible reasons for the increasing yield per hectare might have been due to having the greater number of the tubers so used the seedling to establish which leads high population density per hectare and, these contributes the ability to produce more tuber number. The results of the study are similar to the findings of Kumar et al., (2007) who investigated that marketable yield was significantly varied by variety, location and genotypes $\mathrm{x}$ environment interaction. In addition, Tesfa (2012) reported that an increasing number of rows per unit area increase total yield per hectare and widening inter row spacing also decreased total yield per hectare of pot

\section{Unmarketable tuber yield (t/ha)}

Unmarketable tuber yield of potato was significantly $(\mathrm{P}<0.05)$ affected by main effects cultivar and plant spacing; however, cultivar and spacing did not interacted to influence this parameter as shown table 5 and Appendix 2.

Chala and Local cultivar was recorded highest unmarketable tuber yield followed by Gudene cultivar whereas the lowest was recorded at the cultivar Belete. All cultivar was not showed significant difference among them except cultivar belete. The variation in nonmarketable yield of the genotypes may be due to adaptability, crop maturity, and inherent ability of potato genotypes in producing unmarketable tubers. Bekele (2018) showed that Variation among genotypes of nonmarketable yield could be attributed to their genetic make-up. And also Haile et al., (2015), who pointed out the effects of genotype that significantly influence unmarketable tuber yield.

Unmarketable tuber yield per hectare was significantly affected by plant density. Among the spacing level, $60 \mathrm{x}$ $30 \mathrm{~cm}$ shows maximum unmarketable potato yield (5.43) followed by $75 \times 30 \mathrm{~cm}$ and $90 \times 30 \mathrm{~cm}(5.03,4.59)$ respectively. From all spacing 90 x $30 \mathrm{~cm}$ gave the list unmarketable yield of potato. From this parameter it show us that potato planted with narrow spacing gives maximum unmarketable yield while the spacing was increased the unmarketable yield become decreased.

The higher amounts of unmarketable tuber yield at higher planting density could be due to the fact that at the 
narrower spacing there is stiff inter-plant competition for growth factors, which result in the production of more numbers of undersized tubers. According to Zebenay, 2015 report closer plant spacing increased competition of plants for growth factors due to high number plant per unit area than wider plant spacing which led to producing high number of under size tubers which was high unmarketable tuber yield.

Other factor this result shows us that at closer spacing absence of air circulation resulted in development of disease and associated diseased plants which contribute more for un-marketability. Beukema and Van der zaag (1990) according to them, planting density had a marked effect on unmarketable tuber yield and the highest unmarketable yield recorded from the closer spacing due to higher inter-plant competition and associated small sized tubers

\section{Total tuber number}

Interactive effects of cultivar and plant spacing significantly $(\mathrm{P}<0.05)$ influenced the total tuber number (Table 6 and Appendix 2). Except cultivar Belete, all cultivars resulted their highest tuber numbers at plant spacing of $60 \times 30 \mathrm{~cm}$. The highest total tuber numbers of cultivar Gudene $\left(629374 \mathrm{ha}^{-1}\right)$, cultivar Chala (547295) and Local cultivar (347700) were produced at spacing 60 x $30 \mathrm{~cm}$, whereas cultivar Belete showed its higher total tuber number $(533400)$ at spacing $75 \times 30 \mathrm{~cm}$.

The lowest total tuber numbers (336963) were counted from the cultivar Local at spacing $75 \times 30 \mathrm{~cm}$. The highest total tuber numbers of cultivar Gudene that produced at spacing $60 \mathrm{x} 30 \mathrm{~cm}$ did not showed statistically significant difference from total tuber number resulted at the spacing of $75 \mathrm{~cm} \times 30 \mathrm{~cm}$.

The increase in the tuber number produced per hectare in response to narrowing the seed tuber spacing is due to a stiffer competition among tubers for growth factors, which restricts expansion in size and increases tuber number. Also it might be due to both genetic and environmental factors that play a vital role in stolon development and tuberization process. According to Subarta and Upadhya (1997) report the numbers of tubers per plot depend mainly on the number of stems per plot, total number of stolons and stolons which tuberize. Similar to the result of this study, Patel et al, (2002); Tesfa (2012) reported that total number of tubers per unit area increased linearly with increasing density.

\section{Average tuber number per hill}

Both main effect of cultivar and plant spacing had showed highly significant $(P<0.01)$ effect, whereas the interaction didn't show significant effect on average tuber number per hill (Table7 and Appendix 2)

Higher average tuber number per hill (12.34) was obtained at Gudene cultivar and the lowest average tuber number per hill (7.73) was recorded from the Local cultivar. The variation may be attributed to that the difference in genetic potential among potato varieties. Stolen and tuberilization processes is affected by genetic makeup and environmental factor (Bekele, 2018).

Significantly varied average tuber numbers per plant were recorded from different plant spacing of potato. The result revealed that when the plant space decreasing, the average number of tuber per plant also decrease but total tuber number per hectare increase. The highest (11.92) tuber number per hill was obtained at wider spacing of $90 \times 30 \mathrm{~cm}$ followed by $75 \times 30 \mathrm{~cm}(10.80)$ whereas the lowest (9.06) was obtained at closer spacing of $60 \mathrm{X}$ $30 \mathrm{~cm}$. Decreasing inter row spacing from 90 to $75 \mathrm{~cm}$ average tuber number plant decreased by $10.37 \%$, and again, decreasing inter row spacing from 75 to $60 \mathrm{~cm}$ deceased the average tuber number per plant by $19.2 \%$. At lower plant densities, competition is less, which results in a greater number of tubers per plant, but also in a smaller number of tubers per unit area.

On the other hand, when plant densities increase, the number of tubers per plant decreases, but the number of tubers per unit area generally increases. This probably due to the number of tubers produced depends on the competition among the plant for growth factors such as nutrients, water and light. The results of the study is in line with findings of Zebenay (2015) who elucidated that the higher number of plants produced at closer plant spacing than plants at wider spacing which led to the production of highest number of total tubers per hill.

\section{Marketable tuber number}

The main effect of cultivar and plant spacing and their interaction significantly $(\mathrm{P}<0.05)$ affected marketable tuber number presented table 6 and appendix 2 .

The maximum marketable tuber number per hectare (596113) was recorded at interaction of narrowest plant spacing $(60 \times 30 \mathrm{~cm})$ and cultivar Gudene. Whereas, the lowest marketable tuber number per hectare (278184) 
observed from Local cultivar at spacing of $75 \times 30 \mathrm{~cm}$. Cultivar Gudene and cultivar Chala produced their highest marketable tuber number per hectare at inter row spacing of $60 \mathrm{~cm}$. Cultivar Belete produced its maximum marketable tuber number at $75 \mathrm{~cm}$ inter row spacing and Local cultivar produced its maximum marketable tuber number at widest inter row spacing which was statistically in par with the narrowest inter row spacing by both cultivars. The results showed that cultivar Gudene produced two fold more yield over Local cultivar at the closest inter row spacing.

The result indicates that narrowing plant spacing increases marketable tuber numbers per hectare. This might be payable to the increased plant density per hectare which produced higher tuber numbers per hectare. The result of the current investigation also supported by the findings of various authors, Khajehpour (2006) reported that with increasing plant number, numbers of stems grown from the planted tuber, and consequently, number of produced tubers per stem are increased. Thus, increase in plant density leads to increase in produced tubers. Similarly Kantona et al., (2003); Harnet et al., (2014) were pointed out that where number of marketable yield increased significantly as plant density and tuber yield increased.

\section{Unmarketable tuber number}

Analysis of variance indicated that unmarketable tuber number was significantly $(\mathrm{P}<0.05)$ influenced by the main effect of cultivar and plant spacing while their interaction did not shown a significant difference on unmarketable potato tuber number (Table 7 and appendix 2).

The highest unmarketable tuber number (58794) and the lowest unmarketable tuber number (29496) were counted from the cultivar Local and Belete respectively. According to their order, cultivar Chala and Gudene hold second and third highest unmarketable tuber number next to Local cultivar. Significant difference of unmarketable tuber number was recorded due to plant spacing. Maximum unmarketable number tuber (46508) observed at the spacing $60 \mathrm{x} 30 \mathrm{~cm}$ and minimum unmarketable tuber number (39112) at spacing $90 \times 30 \mathrm{~cm}$.

The result indicates that widening plant spacing decreases the numbers of unmarketable tuber number per hectare. This might be due to the fact that at wider spacing the plants face less competition and resulted in big sized tubers which are marketable. Whereas, at closer spacing, due to more number of plants per unit area, the plants get severe competition and resulted in small sized and diseased tubers and associated high unmarketable tuber per hectare. Consistent with the results of this study, Frezgi (2007) also indicated that closer seed tuber spacing resulted in a significantly higher yield of smallsized tubers as the consequence of higher competition between plants. Similarly, Tesfa (2012); Birhanu et al., (2016) reported that the narrower spacing resulted in the production of large numbers of undersized unmarketable tubers compared to the wider spacing.

\section{Dry matter content}

The dry matter content was significantly $(\mathrm{P}<0.05)$ affected by cultivar and plant spacing but not by their interactions (Appendix 3and Table 8). Gudene and Belete had showed significantly $(\mathrm{P}<0.05)$ highest tuber dry matter $(24.761 \%$ and .... respectively with statistical parity; while the lowest tuber dry matter (13.702\%) was recorded from Local cultivar. Higher dry matter percentage recorded at cultivar that had maximum LAI, it might be the capacity to prepare more photosynthesis and able to produce more assimilates and it is the channeled to sinks and also the inherent genetic differences among the potato varieties in the production of dry matter (total solids) contents of tubers. The present result is in concurred with the finding of Tekalign and Hammes (2005) who reported that significant variation among potato cultivars with respect to total dry matter content was observed.

In this study, the results showed that increasing plant spacing could result in decreasing dry matter content. Thus, the highest tuber dry matter yield (21.575) was recorded at the spacing of $60 \times 30 \mathrm{~cm}$. Conversely, the lowest yield of dry matter (17.947) was obtained at the spacing of $90 \times 30 \mathrm{~cm}$. Hence, increasing inter row spacing from 60 to $75 \mathrm{~cm}$ reduced percentage of tuber dry matter from 19.03 to 17.92 . The result agreed with the finding of Alvin et al., (2007) who reported when plant density increasing, plant dry matter was decreased in each plant but increased per unit area. This finding also in conformity with those reported by Frezgi (2007) that tuber dry matter percentages decreased with increased inter row spacing.

\section{Harvest index}

The result revealed that highly $(\mathrm{P}<0.01)$ significant in response to the main effect of cultivar and plant spacing but not their interaction. (Table 8 and Appendix 3). 
Cultivar Gudene gave significantly the highest value $(0.82)$ of harvest index while Local cultivar had the lowest (0.66) harvest index values. Narrow plant spacing of $60 \times 30 \mathrm{~cm}$ resulted high harvest index over the other spacing $(75 \times 30 \mathrm{~cm}$ and $90 \times 30 \mathrm{~cm})$. The lowest $(0.7105)$ harvest index recorded spacing at $90 \mathrm{~cm} \times 30 \mathrm{~cm}$ whereas the highest $(0.778)$ was at spacing of $60 \times 30 \mathrm{~cm}$. That means most of the time its efficiency related with spacing, there was decreasing trend in harvest index in response to decreasing planting density. According to Beukema and Van der Zaag (1990) study in temperate zone harvest indices of $0.75-0.85$ are quite common but in warmer climates, the harvest index tend to be lower and often a wider variation is also observed between cultivars or growing conditions.

Table.1 Description of studied varieties

\begin{tabular}{|l|l|l|l|l|}
\hline No & Name of variety & Year of release & Breeder/ maintainer & $\begin{array}{l}\text { Recommended } \\
\text { altitude (m.a.s.l) }\end{array}$ \\
\hline 1 & Belete & 2010 & Holeta research center & $1600-2800$ \\
\hline 2 & Gudene & 2006 & Holeta research center & $1600-2800$ \\
\hline 3 & Chala & 2004 & Haramaya University & $1700-2000$ \\
\hline 4 & Local & - & Farmers & 1800 \\
\hline
\end{tabular}

Table.2 Main effect of cultivar and plant spacing on days to 50\% flowering and 90\% maturity in potato at wsu in 2019 cropping season

\begin{tabular}{lll}
\hline Treatment & $50 \%$ flowering (days) & $90 \%$ maturity (days) \\
\hline Cultivar & & \\
Belete & $52.74^{\mathrm{b}}$ & $96.22^{\mathrm{a}}$ \\
Gudene & $54.96^{\mathrm{a}}$ & $93.11^{\mathrm{b}}$ \\
Chala & $49.37^{\mathrm{c}}$ & $86.22^{\mathrm{d}}$ \\
& & \\
Local cultivar & $55.26^{\mathrm{a}}$ & $89.67^{\mathrm{c}}$ \\
& & \\
& & \\
LSD $(0.05)$ & 1.4250 & 2.3927 \\
& & \\
& & \\
\hline Spacing (cm) & & $88.58^{\mathrm{b}}$ \\
$60^{* 30}$ & $52.19^{\mathrm{b}}$ & $91.92^{\mathrm{a}}$ \\
$75^{*} 30$ & $52.66^{\mathrm{b}}$ & $93.42^{\mathrm{a}}$ \\
$90^{*} 30$ & $54.39^{\mathrm{a}}$ & 2.0721 \\
LSD $(0.05)$ & 1.2341 & \\
& & \\
\hline & & \\
CV\% & 2.75 &
\end{tabular}

Means with the same letter(s) within a column are not significantly different at 5\% level of significance. LSD $(5 \%)=$ Least significant difference at $\mathrm{P}=0.05$, and $\mathrm{CV}(\%)=$ Coefficient of variation in percent. 
Table.3 Main effect of cultivar and plant spacing on days to $50 \%$ emergence and stem number per plant in potato at wsu in 2019 cropping season

\begin{tabular}{lll}
\hline Treatment & $50 \%$ emergence (days) & Stem number per plant \\
\hline Cultivar & & \\
Belete & $16.393^{\mathrm{a}}$ & $6.3989^{\mathrm{a}}$ \\
Gudene & $16.226^{\mathrm{a}}$ & $5.9444^{\mathrm{a}}$ \\
Chala & $13.822^{\mathrm{b}}$ & $4.7244^{\mathrm{b}}$ \\
Local cultivar & $16.603^{\mathrm{a}}$ & $4.2000^{\mathrm{b}}$ \\
\hline LSD $(0.05)$ & 2.1839 & 0.8050 \\
& & \\
CV\% & 14.17 & 15.49 \\
\hline
\end{tabular}

Means with the same letter(s) within a column are not significantly different at 5\% level of significance. LSD (5\%) $=$ Least significant difference at $\mathrm{P}=0.05$, and $\mathrm{CV}(\%)=$ Coefficient of variation in percent

Table.4 Main effect of cultivar and plant spacing on leaf area index and plant height at wsu in 2019 cropping season

\begin{tabular}{ccc}
\hline Treatment & Leaf area index & Plant height $(\mathrm{cm})$ \\
\hline $\begin{array}{c}\text { Cultivar } \\
\text { Belete }\end{array}$ & $4.2111^{\mathrm{a}}$ & \\
& & $84.10^{\mathrm{a}}$ \\
Gudene & $4.2556^{\mathrm{a}}$ & $83.96^{\mathrm{a}}$ \\
& & $71.16^{\mathrm{b}}$ \\
Chala & $2.5333^{\mathrm{b}}$ & $63.88^{\mathrm{c}}$ \\
Local & $1.6333^{\mathrm{c}}$ & 4.4544 \\
LSD $(0.05)$ & 0.5132 & $73.358^{\mathrm{b}}$ \\
\hline Spacing & & $75.458^{\mathrm{ab}}$ \\
$60^{*} 30$ & $3.4250^{\mathrm{a}}$ & $78.500^{\mathrm{a}}$ \\
$75 * 30$ & $3.3583^{\mathrm{a}}$ & 3.8576 \\
$90^{*} 30$ & $2.6917^{\mathrm{b}}$ & \\
LSD $(0.05)$ & 0.4444 & 6.01 \\
\hline CV\% & & \\
\hline
\end{tabular}

Note. Means with the same letter(s) within a column are not significantly different at $5 \%$ level of significance, LSD $(5 \%)=$ Least significant difference at $\mathrm{P}=0.05$ 
Table.5 Main effect of cultivar and plant spacing on total tuber yield, average tuber yield, marketable tuber yield and unmarketable tuber yield at wsu in 2019 cropping season

\begin{tabular}{lllll}
\hline Treatment & $\begin{array}{l}\text { Total tuber } \\
\text { Yield t/ha }\end{array}$ & $\begin{array}{l}\text { Total tuber yield } \\
\text { per plant }\end{array}$ & $\begin{array}{l}\text { Marketable } \\
\text { tuber yield t/ha }\end{array}$ & $\begin{array}{l}\text { Unmarketable tuber } \\
\text { yield t/ha }\end{array}$ \\
\hline Cultivar & & & & \\
Belete & $32.26^{\mathrm{ab}}$ & $718.49^{\mathrm{ab}}$ & $27.942^{\mathrm{a}}$ & $4.3156^{\mathrm{b}}$ \\
Gudene & $34.40^{\mathrm{a}}$ & $764.64^{\mathrm{a}}$ & $29.307^{\mathrm{a}}$ & $5.0944^{\mathrm{a}}$ \\
Chala & $29.16^{\mathrm{b}}$ & $651.16^{\mathrm{b}}$ & $23.759^{\mathrm{b}}$ & $5.3989^{\mathrm{a}}$ \\
Local & $23.71^{\mathrm{c}}$ & $528.36^{\mathrm{c}}$ & $18.426^{\mathrm{c}}$ & $5.2833^{\mathrm{a}}$ \\
LSD $(0.05)$ & 3.2473 & 70.867 & 3.1303 & 0.5986 \\
& & & & \\
\hline Spacing & & & & \\
$60 * 30$ & $32.02^{\mathrm{a}}$ & $576.32^{\mathrm{c}}$ & $25.585^{\mathrm{a}}$ & $5.4325^{\mathrm{a}}$ \\
$75^{*} 30$ & $30.06^{\mathrm{ab}}$ & $676.32^{\mathrm{b}}$ & $25.021^{\mathrm{ab}}$ & $5.0375^{\mathrm{ab}}$ \\
$90 * 30$ & $27.57^{\mathrm{b}}$ & $744.35^{\mathrm{a}}$ & $22.969^{\mathrm{b}}$ & $4.5992^{\mathrm{b}}$ \\
LSD $(0.05)$ & 2.8122 & 61.373 & 2.7109 & 0.5184 \\
\hline & & & & \\
CV \% & 11.12 & 10.89 & 12.88 & 12.19 \\
\hline
\end{tabular}

Note. Means with the same letter(s) within a column are not significantly different at $5 \%$ level of significance. NS $=$ nonsignificant difference, $\operatorname{LSD}(5 \%)=$ Least significant difference at $\mathrm{P}=0.05$, and $\mathrm{CV}(\%)=$ Coefficient of variation in percent.

Table.6 The interaction effect of cultivar and plant spacing on total and marketable tuber number per hectare at wsu in 2019 cropping season

\begin{tabular}{llll}
\hline Cultivar & Spacing in $(\mathrm{cm})$ & $\begin{array}{l}\text { Total tuber } \\
\text { number }\end{array}$ & $\begin{array}{l}\text { Marketable } \\
\text { tuber number }\end{array}$ \\
\hline Belete & $60^{*} 30$ & $490620^{\mathrm{bc}}$ & $458469^{\mathrm{bcd}}$ \\
& $75^{*} 30$ & $533400^{\mathrm{b}}$ & $503551^{\mathrm{bc}}$ \\
& $90^{*} 30$ & $418429^{\mathrm{cd}}$ & $391941^{\mathrm{d}}$ \\
Gudene & $60^{*} 30$ & $629374^{\mathrm{a}}$ & $596113^{\mathrm{a}}$ \\
& $75^{*} 30$ & $556680 \mathrm{ab}$ & $522796^{\mathrm{ab}}$ \\
& $90^{*} 30$ & $487648^{\mathrm{bc}}$ & $460206^{\mathrm{bcd}}$ \\
Chala & $60^{*} 30$ & $547295^{\mathrm{b}}$ & $489478^{\mathrm{bc}}$ \\
& $75^{*} 30$ & $493782^{\mathrm{b}}$ & $445361^{\mathrm{cd}}$ \\
& $90^{*} 30$ & $511530^{\mathrm{b}}$ & $463813^{\mathrm{bcd}}$ \\
Local & $60^{*} 30$ & $345881^{\mathrm{de}}$ & $283078^{\mathrm{e}}$ \\
& $75^{*} 30$ & $336963^{\mathrm{e}}$ & $278184^{\mathrm{e}}$ \\
& $90^{*} 30$ & $347700^{\mathrm{de}}$ & $292900^{\mathrm{e}}$ \\
\hline LSD(0.05) & & 76652 & 76553 \\
CV\% & & 9.53 & 10.46
\end{tabular}

Note. Means with the same letter(s) within a column are not significantly different at 5\% level of significance. LSD $(5 \%)=$ Least significant difference at $\mathrm{P}=0.05$, and $\mathrm{CV}(\%)=$ Coefficient of variation in percent. 
Table.7 The main effects of cultivar and plant spacing on unmarketable tuber number and average tuber number at wsu in 2019 cropping season

\begin{tabular}{lll}
\hline Treatment & $\begin{array}{l}\text { Unmarketable tuber } \\
\text { number per hectare }\end{array}$ & $\begin{array}{l}\text { Average tuber number } \\
\text { per plant }\end{array}$ \\
\hline Cultivar & & \\
& & \\
Belete & $29496^{\mathrm{c}}$ & $10.710^{\mathrm{b}}$ \\
Gudene & $31529^{\mathrm{c}}$ & $12.340^{\mathrm{a}}$ \\
Chala & $51318^{\mathrm{b}}$ & $11.591^{\mathrm{ab}}$ \\
Local & $58794^{\mathrm{a}}$ & $7.732^{\mathrm{c}}$ \\
LSD $(0.05)$ & 6800.2 & 0.9519 \\
\hline Spacing $(\mathrm{cm})$ & & \\
$60^{* 30}$ & $46508^{\mathrm{a}}$ & $11.916^{\mathrm{a}}$ \\
$75^{*} 30$ & $42733^{\mathrm{ab}}$ & $10.805^{\mathrm{b}}$ \\
$90^{*} 30$ & $39112^{\mathrm{b}}$ & $11.916^{\mathrm{a}}$ \\
LSD $(0.05)$ & 5889.2 & 0.8244 \\
\hline & & \\
CV\% & 16.26 & 9.19 \\
\hline
\end{tabular}

Note. Means with the same letter(s) within a column are not significantly different at 5\% level of significance. LSD $(5 \%)=$ Least significant difference at $\mathrm{P}=0.05$.

Table.8 Main effect of means for dry matter and harvest index of potato as influenced by cultivars and plant spacing at wsu in 2019 cropping season

\begin{tabular}{lll}
\cline { 1 - 1 } Treatment & Dry matter $(\%)$ & \\
Cultivar & & \\
& & \\
Belete & $22.208^{\mathrm{a}}$ & $0.7642 \mathrm{~b}$ \\
Gudene & $24.761^{\mathrm{a}}$ & $0.8261 \mathrm{a}$ \\
Chala & $17.480^{\mathrm{b}}$ & $0.7467^{\mathrm{b}}$ \\
Local & $13.702^{\mathrm{c}}$ & $0.6610^{\mathrm{c}}$ \\
LSD $(0.05)$ & 3.1615 & 0.0338 \\
\hline Spacing & & \\
$60^{*} 30$ & $21.575^{\mathrm{a}}$ & $0.7787^{\mathrm{a}}$ \\
$75^{*} 30$ & $19.092^{\mathrm{ab}}$ & $0.7593^{\mathrm{a}}$ \\
$90^{*} 30$ & $17.947^{\mathrm{b}}$ & $0.7105^{\mathrm{b}}$ \\
LSD $(0.05)$ & 2.7379 & 0.0293 \\
\hline & 16.55 & 4.62 \\
CV\% & &
\end{tabular}

Note. Means with the same letter(s) within a column are not significantly different at $5 \%$ level of significance. NS $=$ non-significant difference, LSD $(5 \%)=$ Least significant difference at $\mathrm{P}=0.05$, and CV $(\%)=$ Coefficient of variation in percent. 
Appendix table.1 Mean square values for days to $50 \%$ emergence and days to flowering, $90 \%$ maturity, stem number, plant height and leaf area index as influenced by inter row spacing and varieties

\begin{tabular}{|c|c|c|c|c|c|c|c|}
\hline \multirow{2}{*}{$\begin{array}{l}\text { Source of } \\
\text { variations }\end{array}$} & \multirow{2}{*}{$\mathrm{DF}$} & \multicolumn{6}{|c|}{ Means Square } \\
\hline & & $\begin{array}{l}\text { Days to } \\
\text { emergency }\end{array}$ & $\begin{array}{l}\text { Day to } \\
\text { flowering }\end{array}$ & $\begin{array}{l}\text { Day to } \\
\text { Maturity }\end{array}$ & $\begin{array}{l}\text { Stem } \\
\text { number } \\
\text { per plant }\end{array}$ & $\begin{array}{l}\text { Plant } \\
\text { height }\end{array}$ & $\begin{array}{l}\text { Leaf area } \\
\text { index }\end{array}$ \\
\hline Replication & 2 & 0.6112 & 15.6508 & 3.111 & 0.06906 & 214.701 & 0.9025 \\
\hline $\begin{array}{l}\text { Cultivar (A) } \\
\text { Spacing(B) } \\
\text { A*B }\end{array}$ & $\begin{array}{l}3 \\
2 \\
6 \\
\end{array}$ & $\begin{array}{l}15.2521^{*} \\
3.1169^{\mathrm{ns}} \\
5.0062^{\mathrm{ns}}\end{array}$ & $\begin{array}{l}66.4932^{* *} \\
16.2399^{* *} \\
4.1187^{\mathrm{ns}}\end{array}$ & $\begin{array}{l}167.880^{* *} \\
73.444^{* *} \\
7.519^{\mathrm{ns}}\end{array}$ & $\begin{array}{l}2.63690^{\text {** }} \\
0.72601^{\mathrm{ns}} \\
2.22615^{\mathrm{ns}}\end{array}$ & $\begin{array}{l}897.331^{*} \\
80.197^{*} \\
28.161^{\mathrm{ns}}\end{array}$ & $\begin{array}{l}15.0855^{* *} \\
1.9733^{* *} \\
0.2996^{\mathrm{ns}}\end{array}$ \\
\hline Error & 2 & 4.9900 & 2.1246 & 5.990 & 0.65721 & 20.760 & 0.2755 \\
\hline $\mathrm{CV} \%$ & & 14.17 & 2.75 & 2.68 & 16.41 & 6.01 & 16.62 \\
\hline
\end{tabular}


Int.J.Curr.Res.Aca.Rev.2021; 9(01): 103-125

Appendix.2 Means squares for total tuber yield $\mathrm{ha}^{-1}$, average tuber yield per plant, marketable tuber yield ha ${ }^{-1}$, and unmarketable tuber yield ha ${ }^{-1}$, total tuber number $\mathrm{ha}^{-1}$, average tuber number per plant, marketable tuber number ha ${ }^{-1}$, and number of unmarketable tuber

\begin{tabular}{|c|c|c|c|c|c|c|c|c|c|}
\hline \multirow{2}{*}{$\begin{array}{l}\text { Source of } \\
\text { variations }\end{array}$} & \multirow[b]{2}{*}{$\mathrm{DF}$} & \multicolumn{8}{|c|}{ Means Squares } \\
\hline & & $\begin{array}{l}\text { Total tuber } \\
\text { yield }\end{array}$ & $\begin{array}{l}\text { Average } \\
\text { tuber yield }\end{array}$ & $\begin{array}{l}\text { Marketable } \\
\text { tuber yield }\end{array}$ & $\begin{array}{l}\text { Unmarketabl } \\
\text { e tuber yield }\end{array}$ & $\begin{array}{l}\text { Total tuber } \\
\text { number }\end{array}$ & $\begin{array}{l}\text { Average } \\
\text { tuber number }\end{array}$ & $\begin{array}{l}\text { Marketable } \\
\text { tuber number }\end{array}$ & $\begin{array}{l}\text { Unmarketable } \\
\text { tuber number }\end{array}$ \\
\hline Replication & 2 & 1.994 & 1136.1 & 0.187 & 1.13954 & 1.18 & 0.4713 & 1.65 & 3.90 \\
\hline Cultivar(A) & 3 & $194.095^{*}$ & $94942.9^{* * *}$ & $215.7^{*}$ & $2.14394^{*}$ & $7.80^{*}$ & $36.7461^{* * *}$ & $9.64^{*}$ & $1.89^{*}$ \\
\hline Spacing(B) & 2 & $59.667^{*}$ & $85719.4^{* * *}$ & $39.5^{*}$ & $2.08521^{*}$ & $1.17^{*}$ & $24.8807^{* *}$ & $9.19^{*}$ & $1.64^{*}$ \\
\hline $\mathrm{A} * \mathrm{~B}$ & 6 & $9.635^{\mathrm{ns}}$ & $4736.4^{\mathrm{ns}}$ & $10.4^{\mathrm{ns}}$ & $0.33595^{\mathrm{ns}}$ & $5.25^{* *}$ & $1.9581^{\mathrm{ns}}$ & $5.26^{*}$ & $1.38^{\mathrm{ns}}$ \\
\hline Error & 22 & 11.033 & 5254.6 & 10.2 & 0.37491 & 2.05 & 0.9481 & 2.04 & 4.83 \\
\hline $\mathrm{CV} \%$ & & 11.12 & 10.89 & 12.8 & 12.19 & 9.53 & 9.19 & 10.46 & 16.26 \\
\hline
\end{tabular}

*and ** = Significant, highly significant difference at $0.5 \%$ and $0.1 \%$ probability levels, respectively. Ns = Non-significant. 
Appendix 3 Means squares for harvest index and dry matter.

\begin{tabular}{l|l|c|l}
\hline $\begin{array}{l}\text { Source of } \\
\text { variations }\end{array}$ & \multirow{2}{*}{ DF } & \multicolumn{2}{|c}{ Mean Squares } \\
\cline { 3 - 4 } & & Harvest index & Dry matter \\
\hline Replication & 2 & 0.00065 & 3.106 \\
& & $0.04178^{* *}$ & $218.101^{*}$ \\
Cultivar(A) & 3 & $0.01481^{* *}$ & $41.286^{*}$ \\
Spacing(B) & 2 & $0.00082^{\mathrm{ns}}$ & $4.000^{\mathrm{ns}}$ \\
A*B & 6 & 0.00120 & 10.458 \\
Error & 22 & & \\
\hline & & & 16.55 \\
CV\% & & 4.62 & \\
\hline
\end{tabular}

$*$ and $* *=$ Significant, highly significant difference at $0.5 \%$ and $0.1 \%$ probability levels, respectively. $\mathrm{N} s=$ Non-significant.

Summery and recommendation are as follows:

Potato (Solanum tuberosum L.) is one of the most important food crops as it is the source of food, employment and income in developing countries. Optimum plant density is one of the most important practices in potato production management, as it affects seed cost, plant development, yield and the quality of the crop. An optimal plant density of a particular cultivar grown using its optimum spacing requirement manifests its performance by showing optimal growth through efficient utilization of moisture, nutrients and light.

Field experiment was conducted at WSU.during belg cropping season to elucidate the response of potato cultivars to different plant spacing and recommend optimum plant spacing for potato production in the area. A factorial arrangement consisting of four potato cultivars (Gudenie, Belete, Chala and Local) and three plant spacing $(60 \times 30 \mathrm{~cm}, 75 \times 30 \mathrm{~cm}$, and $90 \times 30 \mathrm{~cm})$ was laid out in a Randomized Complete Block Design (RCBD) with three replications. Data were collected on phenology, growth, yield and yield components and tuber quality related traits and subjected to appropriate statistical analysis. The result showed that all measured parameters were significantly $(\mathrm{P}<0.05)$ affected due to the main effect of cultivar and plant spacing whiles their interaction was non-significant $(\mathrm{P} \geq 0.05)$ except total and marketable tuber number.

The maximum total tuber yield, average total yield per plant, marketable tuber yield, total tuber number, average tuber number per hill, and marketable tuber number recorded from cultivar Gudene whereas, the lowest data recorded from Local variety. Cultivar Gudene produced $45.08 \%, 17.96 \%$ and $6.6 \%$ more total tuber yield over Local, Chala and Belete respectively. However, the result was statistically in par with cultivar Belete. Cultivar Gudene and Belete produced more than one fold marketable tuber yield over Local cultivar.

On the other hand highest total tuber yield, marketable tuber yield, total tuber number, average tuber number per hill, and marketable tuber number scored at spacing of $60 \times 30 \mathrm{~cm}$ and $75 \times 30 \mathrm{~cm}$ with statistical parity. Therefore, from this study, it can be concluded Gudane and Belete cultivars at a plant spacing of $60 \times 30 \mathrm{~cm}$ and $75 \times 30 \mathrm{~cm}$ resulted in highest marketable tuber yield could be recommended to potato growers in the study area.

The results obtained in this research are based on one season data and at one location. To come up with conclusive results, further study may consider assessing the effect cultivar and plant spacing on yield and yield component of potato in different location.

\section{References}

Abay Ayalew and Tesfaye Dejene. (2011). Integrated Application of Compost and Inorganic Fertilizers for Production of Potato (Solanum tuberosum L.) at Angacha and Kokate in Southern Ethiopia. Journal of Biology, Agriculture and Healthcare, 1(2):15-24.

Abebe, G.K., Bijman, J., Ruben, R., Omta, O., Tsegaye, A., (2010). The role of seed/ware potato cooperatives in Ethiopia in improving quality and reducing transaction costs. Paper Presented at the 
9th Wageningen International Conference on Chain and Network Management, 26-28May 2010, Wageningen, The Netherlands.

Abong go et al., (2010). Evaluation of selected Kenyan potato cultivars for processing into potato crisps. Agriculture and Biology Journal of North America 1: 886-893.

Abubaker S, A. AbuRayyan, A. Amre, Y. Alzu`bi1, N. Hadidi,(2011). Impact of Cultivar and Growing Season on Potato (Solanum tuberosum L.), Under Center Pivot Irrigation System. World J. Agric. Sci. 7 (6): 718-721.

AGRISNET (Agriculture Information System Network), (2010). Department of Agriculture Government of Sikkim. India. http://www.sikkimagrisnet.org General/en/Agriculture/ Potato Soil_Requirement.aspx.

AlemayehuT,D.Nigussie, T. Tamado (2015). Response of Potato (Solanumtuberosum +L.) Yield and Yield Components to Nitrogen Fertilizer and Planting Density at Haramaya, Eastern Ethiopia. Journal of Plant Sciences 3(6):320-328.

Allen, E.J., D.C.E. Wurr and J.R. Fellows, (1992). Determination of optimum tuber planting density in the potato varieties, Pent land Squire, Cara, Estima, Maris Piper and King Edward. $J$ AgricSciCamb119:35-44

Alsharari, S. F., A. A.Alsadon, and A. R. Alharbi, (2007). Evaluation of water stress tolerance of potato cultivars under greenhouse conditions. Proceedings of the VIII ${ }^{\text {th }}$ IS on Protected Cultivation in Mild Winter Climates. Acta Horticulture, 747:67-74

Alvin, J.B., P.D. Mitchell, M.E. Copas and M.J. Drilias, (2007). Evaluation of the Effect of Density on Potato Yield and Tuber Size Distribution. Crop science society of America 47: 2462-2472.

Ankumah, R.O., V. Khan, K. Mwamba and K. Kpomblekou, (2003). The influence of source and timing of nitrogen fertilizers on yield and nitrogen use efficiency of four sweet potato cultivars. Agric. Ecosyst. Environ., 100: 201-207.

Arega A, Tekalign A, Solomon T, Tekile B, (2018). Effect of Inter and Intra Row Spacing on Tuber Yield and Yield Components of Potato (Solanum tuberosum L.) in Guji zone, Southern Ethiopia. J Adv Plant Sci 1: 102.

Arega, D.A; Manyoung, V.M; Omanya G; Mignouna H.D; Bakanga M; and Odhiambo, G.D, (2007). Smallholder Marketed surplus and Input NSE under transactions costs: Maize supply and fertilizer Demand in Kenya AAAE Conference Proceedings PP 125-130.
Asfaw F (2016). Effect of integrated soil amendment practices on growth and seed tuber yield of potato (Solanum tuberosum L.) at Jimma Arjo, Western Ethiopia. Journal of Natural Sciences Research 6(15):38-63.

Asresie Hassen, Alemu Worku, Molla Tafere, Mekonen Tolla, Abel Ahmed, Seferew Dagnew, Yihenew G.Selassie, Desallegn Molla and Tesfaye Abebe, (2015). Best Fit Practice Manual for Potato Production and Utilization. BDU-CASCAPE working paper 8 .

Bekele T (2018). Adaptability study of improved potato (Solanum tuberosumL.) varieties at Shebench District, South-western Ethiopia. Acad. J. Agric. Res. 6(10): 333-339.

Beukema, H.P. and D.E. Van der Zaag, (1990). Introduction to potato production. Center for agricultural publishing and documentation, pudoc. Wageningen, the Netherlands.208p

Birhanu Tsegaye, Nigussie Dechassa and Wassu Mohammed (2016).Growth and yield of potato (Solanum tuberosum L.) cultivars as influenced by plant spacing at Haramaya and Hirna, Eastern Ethiopia. Journal of Horticulture and Forestry Vol. 10(5), pp.52-62.

Bussan AJ, PD.Mitchell, ME.Copas, MJ.Drilias, (2007). Evaluation of the effect of potato yield and tuber size distribution. J Crop Sci 47: 2462-72.

Ceglarek F., K. Zarzecka, W. Ziemniak.: Z. Jasig̀skai, A. Kotecki (red.), Szczegóğowauprawaro1lin, t.1.. Wyd. AWA Wrocğaw, (2003), s. 315-373.

CSA(Central statistical agency),(2016). Agricultural sample survey, report on area, production and farm management practice of belg season crops for private peasant holdings. Volume V, Statistical Bulletin 578. Addis Ababa, Ethiopia.

CSA (Central Statistical Agency). (2017). Report on Area and Production of Major Crops (Private Peasant Holdings, Meher Season). The Federal Democratic Republic of Ethiopia Agricultural Sample Survey, Volume I, Statistical Bulletin 532, Addis Ababa, Ethiopia.

CSA (Central Statistical Agency). (2018). Report on Area and Production of Major Crops (Private Peasant Holdings, Meher Season). The Federal Democratic Republic of Ethiopia Agricultural Sample Survey, Volume I, Statistical Bulletin 589, Addis Ababa, Ethiopia

Damavandi A. and R. Asle-Gorgani (2005). Effect of cultivar and plant density on growth and distribution of dry matter in potatoes. Journal of Agricultural Science. 15(4), 25-39. 
Djilani GA, M. Senoussi (2013). Influence of organic manure on the vegetative growth and tuber production of potato (Solanum tuberosum Lvarspunta) in a Sahara desert region. Algeria, International Journal of Agriculture and Crop Sciences 5(22):2724-2731.

Elfinesh F (2008). Processing Quality of Improved potato (Solanum tuberosum L.) Varieties as Influenced by Growing Environment, Genotype and Blanching. MSc. Thesis submitted to school of plant sciences, Haramaya University, Ethiopia.

El-Naim, A.M., (2003). Effect of different irrigation water quantities and cultivars on growth and yield of sesame (Sesamum indicum L.) Ph.D. Thesis, faculty of Agricultural University of Khartoum.75p.

Endale Gebre and Gebremedhin Woldegiorgis. (2001). Effects of Spatial Arrangement on Tuber Yields of Some Potato Cultivars Ethiopian Agriculture Research Organisation, Holetta Research Centre, P. O. Box 2003/6282, Addis Ababa, Ethiopia, African Crop Science Journal, 9(1): 67-76.

Ermias Elka and Fanuel Laekemariam (2020). Effects of Organic Nutrient Sources and NPS Fertilizer on the Agronomic and Economic Performance of Haricot Bean (Phaseolus vulgaris L.) in Southern Ethiopia", Applied and Environmental Soil Science, Journals, Volume 12, Page 1-9

FAO, (2008). Production year book. Food and Agriculture Organization of the United Nations, Rome, Italy.

FAO, (2010). Production year book. Food and Agriculture Organization of the United Nations, Rome, Italy.

FAOSTAT (2008). Country Profile on Potato Production and utilization: Ethiopia. In Gebremedhin ,W., Endale, G., and Kiflu , B. 2001. National potato research program report. Ethiopia Agricultural Research Organization, Holetta Agricultural Research Center.

FAOSTAT data, (2010). Agricultural data. Provisional (2010). Production Indices Data. Crop Primary. (http://apps.fao.org/default.jsp).

Frezgi Asgedom,(2007).Effect of Planting Density and Nitrogen Application on Yield and Yield Components of Potato (Solanum tuberosum L.) at Enderta, Southern Tigray, Ethiopia. MSc. Thesis submitted to school of plant sciences, Haramaya university ,Ethiopia.

Gebremedhin W, Endale G, Kiflu B (2013). National potato research program report. Ethiopian Agricultural Research Organization, Holetta Agricultural Research Center.pp.125.
Gebremedhin, W., G. Endale, and B. Lemaga, (2008). Potato variety development. In Root and tuber crops: The untapped resources, ed. W. Gebremedhin, G. Endale, and B.Lemaga, 1532.Addis Abeba: Ethiopian Institute of Agricultural Research.

Georgakis, D.N., D.I. Karafyllidis, N.I. Stavropoulos, E.X. Nianiou, and I.A. Vezyroglou, (1997).Effect of planting density and size of potato seed-mini tubers on the size of the produced potato seed tubers. Acta Hort. 462: 935-942.

Geremew A, A Teshome, T Kasaye, C Amenti (2010). Effects of intra row spacing on yield of three onion (Allium cepa I.) variety at Adami Tulu agriculture research center (mid rift valley of Ethiopia). J. Horticulture Forestry 2(1):007-011 January 2010.

Gulluoglu, L. and H. Arioglu, (2009). Effects of seed size and in-row spacing on growth and yield of early potato in a Mediterranean-type environment in Turkey. Afr. J. Agric. Res., 4: 535-541.

Haile B, Mohammed A, Woldegiorgis G (2015). Effect of Planting Date on Growth anTuber Yield of Potato (Solanum tuberosum L.)Varieties at Anderacha District, Southwestern

Harnet A (2011). Effect of inter and intra row spacing on seed tuber yield and yield components of potato (Solanum tuberosum L.) at Ofla Woreda, Northern Ethiopia. MSc. Haramaya University, Ethiopia.

Harnet A, B. Derbew, W. Gebermedhihin, (2014). Effect of inter and intra row spacing on seed tuber yield and yield components of potato (Solanum tuberosum L.) at OflaWoreda, Northern Ethiopia. African Journal of Agricultural Research.8 (6).285290.

Hirpa, A. Meuwissen, M.P.M., Tesfaye, A., Lommen, W.J.M., Lansink, A.O., Tsegaye, A. and Struik, P.C. (2010). Analysis of seed potato systems in Ethiopia. American Journal of Potato Research, 87: 537-552.

Gebru, H., A. Mohammed, N. Dechassa, D. Belew (2017). Assessment of production practices of smallholder potato (Solanum tuberosum L.) farmers in Wolaita zone, southern Ethiopia Agric. Food Secur., 6 (1), p. 31.

Islam, S. (2006). "Sweet potato Leaf: Its Potential Effect on Human Health and Nutrition," J. Food Sci. 71:R13R21.

Kantona, R. A. L., L. Abbeyb, R. G. Hillac, M. A. Tabil and N. D. Jane, (2003). Density Affects Plant Development and Yield of Bulb Onion (Allium cepa L.) in Northern Ghana. Journal of Vegetable Crop Production, Volume 8, pages 15-25. 
Khajehpour, M., (2006). Production of industrial plants. Jehad-e-Daneshgahi Isfahan press, Isfahan. Iran.580: ISBN 961-6122-63-9

Khalafalla, A. M., (2001). Effect of Plant Density and Seed Size on Growth and Yield of Solanum Potato in Khartoum State, Sudan African Crop Science Journal, 9(1): 77- 82.

Kooman, P.L., M. Fahem, P. Tegera, and A.J. Haverkort. (1996a). Effects of climate on different potato genotypes. 1. Radiation interception, total and tuber dry matter production. Eur. J. Agron. 5:193-205. doi:10.1016/S1161-0301(96)02031-X

Kooman, P.L., M. Fahem, P. Tegera, and A.J. Haverkort. (1996b). Effects of climate on different potato genotypes. 2. Dry matter allocation and duration of the growth cycle. Eur. J. Agron. 5:207-217. doi:10.1016/S1161-0301(96)02032-1

Kumar, P., Pandey, S. K., Singh, B. P., Singh, S. V., Kumar, D. (2007) Effect of nitrogen rate on growth, yield, economics and crisps quality of Indian potato processing cultivars. Potato Res., 50, 143-155.

Levy D, RE .Veilleux (2007). Adaptation of Potato to High Temperatures and Salinity A Review. Amer. J. Potato Res. 84: 487-506.

Mahmood, S., (2005). A study of planting method and spacing of Potato using TPS. Asian journal of plant sciences and Department of soils and nutrition, Bangladesh sugarcane research institute, Pabna, Bangladesh.

Marguerite, O., G. Jean-Pierre and L. Jean-Francois, (2006). Threshold value for chlorophyll meter as decision tool for nitrogen management of potato. Agron. J., 98: 496-506.

Masarirambi, M.T., F.C. Mandisodza, A.B. Mashingaidze and E. Bhebhe, (2012). Influence of plant population and seed tuber size on growth and yield components of potato (Solanum tuberosum L). Int. J. Agric. Biol., 14: 545-549

Mauromicale, G., P. Signorelli, A. Ierna and S. Foti,(2003). Effects of intra specific competition on yield of early potato grown in Mediterranean environment. Am. J.Potato Res., 80: 282-288.

Melito S, V. Damelia, R Garraaone, C Villano, D .Carputo (2017). Tuber yield and processing traits of potato advanced selections. Advances in Horticultural Science 31(3): 151-156

Mengistu, T. and C. Yamoah, (2010). Effect of sowing date and planting density on seed production of carrot (Daucuscarota var. sativa) in Ethiopia. Afr. J. Plant Sci., 4: 270-279.

Musa F, B. Defrime, K. Bakir, R Imer, Z .Osman, B Ramiz, L. Isuf (2007). Tuber yield and other relevant parameters of some Netherlands potato varieties in agro-climatic conditions of Kosova.44th Croatian \& $4^{\text {th }}$ International Symposium on Agriculture. Pp 444-448.

Norman, J. C. (1992). Tropical Vegetable Crops. Arthur H. Publishers. Stockwell Ltd. Great Britain.

Patel, B. T., Barad, A.V., Chaudhari, S.M., Patel, C. K. and Patel, R. N. (2002) Standardization of spacing for seed tuberlet production from TPS under nursery beds in Gujarat. Indian J. Potato. Assoc. 29(3/4): 143-146.

RajasekaranLr; T .Astatkie; C .Caldwell. (2006). Seeding rate and seed spacing modulate root yield and recovery of slicer and dicer carrots differently. Scientia Horticulturae 107:319-324.

Ratta, A., R.L. Vanderlip, R.A. Higgins, L.J. Moshier and A.M. Feyerherm. (1991). Suitability of corn growth models for incorporation of weed and insect stresses. Agron. J., 83: 757- 765 .

Ravichandran, G. and S.Singh, (2003). Maximization of seed size tubers through size of tubers, spacing and haulm killing in the Nilgiris. Indian J. Pot .Assoc. 30(1/2): 47-48.

Ronald, A., (2005). Effect of pre-harvest management on yield, process quality, and disease development in Russet Burbank potatoes. M.Sc. Thesis, the University of Manitoba Winnipeg, p.174.

Rosa, P. M., Campos, T. de, Sousa, A. C. B. de, Sforça, D. A., Torres, G. A. M., \& Souza, A. P.de. (2010). Potato cultivar identification using molecular markers. Pesquisa Agropecuária Brasileira, 45(1), 110-113.

Sadik Ebrahim, Hussien Mohammed and Tewodros Ayalew (2018). Effects of seed tuber size on growth and yield performance of potato (Solanum tuberosum L.) varieties under field conditions. African Journal of Agricultural ResearchVol. 13(39), pp. 2077-2086.

Saluzzo, J.A., H.E. Echeverria, F.H. Andrade and M. Huarte, (1999). Nitrogen nutrition of potato cultivars differing in maturity. Journal of Agronomy and Crop Science, 183:157-165.

Sands, P.J.; C. Hackett, (1983); Nix, H.A.A model of the development and bulking of potatoes (Solanum tuberosum L.). I. Derivation from well-managed field crops. Field Crops Research, Amsterdam, v.2, p.309$331,1983$.

SAS Institute Inc. (2008). SAS/STAT. 9.2 User's Guide. Cary, NC: SAS Institute Inc. USA.

Silva J.B.C., J. V. Vieira, and M.M. Lana, (2008). Processing yield of carrot cultivar Esplanada as affected by harvest time and planting density. Sci. Hortic. 115: 218- 222 
Silvertooth, C.J. (200). Row spacing plant population, and yield relationships. Internet document. http://cals.arizona.edu/crop/cotton/comments/ aprill999cc.html.

Struik,P.C., and S.G. Wiersema.(1999). Seed potato technology, 383. Wageningen: Wageningen Pers.

Subarta M. and M.O .Upadhya , (1997). Potato production in western Bengal. Environmental. Ecology Journal.15:646-900.

Sultana, N. and M.A. Siddique, (1991). Effect of cut seed piece and plant spacing on the yield and profitability of potato.Bangladesh Hort., 19 (1):37-43.

Tekalign T, Hammes PS (2005). Growth and productivity of potato as influenced by cultivar and reproductive growth I, stomatal conductance, rate of transpiration, net photosynthesis and dry matter production and allocation. Scientia Horticulturae 105(1):13-27.

Tesfa Binalfew, (2012).M.Sc thesis on Influence Of Plant Spacing on Seed Tuber Production Of Potato (Solanum tuberosum L.) Cultivars Grown In Eastern Ethiopia.

Van Delden A (2001). Yield and growth components of potato and wheat under organic nitrogen management. Agronomy Journal 93: 1370-1385.

Van der Zaag P, Demagante AL, Ewing EE (1990). Influence of plant spacing on potato (Solanum tuberosum L.) morphology, growth and yield under two contrasting environments. Potato Res. 33(3):313-323.

Vleeshouwers, V. G., Raffaele, S., Vossen, J. H., Champouret, N., Oliva, R., Segretin, M. E., ... Pel, M. A. (2011).Understanding and exploiting late blight resistance in the age of effectors. Annual Review of Phytopathology, 49, 507-531.

Vreugdenhil D (2007) Potato biology and biotechnology advances and perspectives. Elsevier Ltd 823.

Winch, T. (2006). Growing food: A guide to food production. Dordrecht, The Netherlands: Springer.

Woldemariam W (2009). Effect of set size and spacing on growth and yield of ginger (Zingiber officinale rocs.) at Areka, Southern Ethiopia.

Zamil MF, MM .Rahman, MG. Robbani, TK .Khatun (2010). Combined effect of nitrogen and plant spacing on the growth and yield of potato with economic performance. Bangladesh Res Publication J 3: 1062.

Zebenay D (2015). Influence of Seed Tuber Size and Plant Spacing On Yield and Quality of Potato (Solanum TUBEROSUML.)In Holeta, Central Ethiopia. MSc thesis pp. 7-13.

\section{How to cite this article:}

Taye Buke, Tsigereda Asefa and Woldemariam Woelore. 2021. Effect of Plant Spacing on Yield and Yield Components of Potato (Solanum tuberosum L.) Cultivars at Wolaita Sodo University, Ethiopia. Int.J.Curr.Res.Aca.Rev. 9(01), 103-125. doi: https://doi.org/10.20546/ijcrar.2021.901.010 